PROFESSOR MARIA DOS ANJOS PIRES (Orcid ID : 0000-0001-9473-5283)

Article type : Short Communication

Authorship Statement:

MAP \& FS performed the histopathological diagnose; JC and MAP performed the immunohistochemistry; RP-C, MAP and FS evaluated the immunohistochemistry; LO was the consultant in neuropathology; MAP, RP-C and JC contributed to the manuscript writing and the reviewing of the literature. All the authors read and approved the content of the MS

Corresponding author mail id: apires@utad.pt

\title{
Co-existing monophasic teratoma and uterine adenocarcinoma in a female dog
}

Pires, M.A. ${ }^{1 *}$, Catarino, J. ${ }^{2}$, Vilhena, $\mathrm{H} .^{1,3}$, Faim, S. ${ }^{4}$, Neves, T. $^{4}$, Freire A. ${ }^{4}$, Seixas, F. ${ }^{1}$, Leonor Orge ${ }^{1,5}$, Payan-Carreira R. ${ }^{1,6}$

${ }^{1}$ Animal and Veterinary Research Centre (CECAV), University of Trás-os-Montes and Alto Douro (UTAD), Quinta de Prados, 5000-801, Vila Real, Portugal

${ }^{2}$ Universidade Lusofona de Humanidades e Tecnologias, Medicina Veterinária, Lisboa, Lisboa, PT

3 Baixo Vouga Veterinary Hospital, EN1, 355, 3750-742, Águeda, Portugal and Centre for Investigation Vasco da Gama (CIVG), Department of Veterinary Medicine, Vasco da Gama University School, Av. José R. Sousa Fernandes, 197 Lordemão, 3020-210, Coimbra, Portugal

${ }^{4}$ University Veterinary Hospital of Coimbra, Av José R Sousa Fernandes, 197, 3020-210 Lordemão, Coimbra, Portugal

${ }^{5}$ Pathology Laboratory, UEISPSA, Instituto Nacional de Investigação Agrária e Veterinária (INIAV), I.P., Av. República, Quinta do Marquês, 2780-157 Oeiras, Portugal

${ }^{6}$ Dept. Veterinary Medicine, School of Sciences and Tecnology, Pole of Mitra 7002-554, Univ. of Évora, Évora, Portugal.

This article has been accepted for publication and undergone full peer review but has not been through the copyediting, typesetting, pagination and proofreading process, which may lead to differences between this version and the Version of Record. Please cite this article as doi: $10.1111 /$ rda.13430

This article is protected by copyright. All rights reserved. 


\section{Abstract}

Ovarian teratomas are occasionally reported in dogs; the rarest type is the monophasic teratoma, composed of tissues originating from only one germ layer. Canine endometrial adenocarcinomas are also rare in dogs and mainly affect geriatric females.

This report describes case of co-existing ovarian teratoma and uterine adenocarcinoma in a 10-yearold nulliparous female Boxer presented with lethargy, anorexia and purulent vaginal discharge. Abdominal ultrasonography evidenced pyometra and a mass in the left ovary. This was composed of a uniform whitish tissue with multiple cystic structures. The histology revealed an atrophy of the ovarian parenchyma, compressed by a proliferation of well-differentiated nervous tissue staining positively to vimentin, S100 and neuronal specific enolase (NSE), and negatively to keratin and inhibin. The left uterine horn, whose diameter was markedly increased, showed foci of endometrial cellular atypia, evident nucleoli and mitoses, at light microscopy.

To our best knowledge, this is the first report of a coexisting ovarian monophasic teratoma and endometrial adenocarcinoma, two rare reproductive neoplasia in dogs.

Keywords: Monophasic teratoma, endometrial adenocarcinoma, dog

\section{Introduction}

Primary ovarian neoplasms account for $6.25 \%$ of the neoplasms in intact bitches, but only $0.45-1.2 \%$ of all canine neoplasms (Pires et al. 2003; Saba and Lawrence 2017). Teratomas are the rarest ovarian tumors ( 2 to $10 \%$ of all ovary tumors) in dogs, and affect mainly adult and geriatric patients (Rota et al. 2013). Arising from totipotent germ cells, they are characteristically composed of tissue derived from any of the three different embryonic germ layers (Nagashima et al. 2000). When only one germ layer component is present, they are classified as monophasic (Rota et al. 2013).

In general, well-differentiated teratomas display a benign biological behavior, remaining unnoticed through large periods of time. Conversely, malignant variants (teratocarcinomas) present proliferation of poorly differentiated cells from multiple origins, with high metastatic potential (rates of $30-50 \%$ ). Metastases have been reported in the peritoneum, kidney, abdominal lymph nodes, lungs, adrenal glands and bones (Saba and Lawrence 2012). Initially, teratomas evolve silently, but show clinical signs after a given size or in malignant conditions, such as a palpable abdominal mass,

This article is protected by copyright. All rights reserved. 
abdominal discomfort, fever, apathy, lameness, vomiting, weight loss and anorexia (Greenlee and Patnaik 1985).

Uterine tumors are also uncommon in dogs (prevalence of $0.3-0.4 \%$ ), affecting mainly middle-aged to geriatric females. They can be classified as epithelial or mesenchymal in origin. Epithelial tumors may be separated in adenoma and adenocarcinoma, which are the rarest type (Pires et al. 2010). Leiomyoma is the most common uterine tumor, comprising $85-90 \%$ of the cases described (Saba and Lawrence 2012). The clinical signs of uterine adenocarcinoma resemble those of other uterine diseases, namely purulent or hemorrhagic vaginal discharge, dysuria/hematuria, anorexia, abdominal pain, abdominal distension and anorexia (Pires et al. 2010).

Albeit ovarian and uterine masses may be identified using imaging diagnostic, but only histopathology provides a conclusive diagnosis (Coggeshall et al, 2012). Ovariohysterectomy is recommended as treatment in most cases and is curative if no metastatic disease is present (Saba and Lawrence, 2012).

This report describes two rare reproductive neoplasms coexisting in a Boxer female dog. To our best knowledge, this is the first report of concomitant ovarian monophasic teratoma and uterine adenocarcinoma described in the dog.

\section{Case Report}

A 10-year-old nulliparous female Boxer was admitted to the University Veterinary Hospital of Coimbra due to lethargy, anorexia and purulent vaginal discharge. Anamnesis highlighted existing regular estrous cycles at six months intervals, and inexistence of contraceptive treatments. Last estrus was recorded 5 months ago. The clinical and gynecologic examinations were completed with hematology [showed mild neutrophilia (13.66 $\times 10^{3} / \mu$; supplementary table 1 ], serum biochemistry (glucose, serum total protein, BUN and creatinine within normal values; supplementary table 2), urinalysis [decreased urine density (1.020)] and abdominal ultrasonography (showing uterine distension by fluid and a mass in the left ovary). Ovariohysterectomy was recommended for suspected pyometra. Recovery from the surgery was uneventful and the dog was discharged 48 hours after surgery with large spectrum antibiotherapy (amoxicillin and clavulanic acid, $20 \mathrm{mg} / \mathrm{kg}$, $\mathrm{q} 12 \mathrm{~h}, 10$ days) and non-steroidal anti-inflammatory (meloxicam, $0.1 \mathrm{mg} / \mathrm{kg}, \mathrm{q} 24 \mathrm{~h}$, five days) medication. The post-surgical follow-up appointments were uneventful. Clinical controls, including abdominal ultrasonography, were performed at one, three, six, nine and 12 months after surgery. The animal was disease-free at the 12-month post-surgery control.

This article is protected by copyright. All rights reserved. 
The resected genital tract was fixed in $10 \%$ buffered formalin and submitted to the histopathological evaluation. At inspection, an enlarged and irregularly shaped left ovary (Figure1) was found, with $8 \times 5 \times 4 \mathrm{~cm}$ (length $x$ width $x$ thickness), but the right ovary $(2.5 \times 1.5 \times 1.5 \mathrm{~cm})$ was morphologically normal. On cross-section, the left ovary presented a uniform, compact mass tissue affecting the majority of the parenchyma, which was reduced to a margin with $0.3 \mathrm{~mm}$, and multiple cystic structures, the biggest with $3 \mathrm{~cm}$ in diameter. The uterus presented an irregular morphology and a hemorrhagic content (right horn: $22 \times 2 \mathrm{~cm}$; left horn: $30 \times 3.5 \mathrm{~cm}$ in length and diameter, respectively). Beside the marked dilation, the left uterine horn showed multiple adhesions between its cranial end and the ovarian bursa, displacing the ovary to the mesometrial side of the uterine horn.

Ovarian and uterine sections were routinely processed, paraffin embedded, and stained with hematoxylin-eosin (H-E). Immunohistochemistry was performed with specific antibodies against neuronal specific enolase (NSE), S-100, vimentin, broad-spectrum cytokeratin (CK) AE1-AE3, CK7, and inhibin (Table 1), with 3,3-Diaminobenzidine (DAB) as chromogen and Gill's Hematoxylin for counterstaining.

Histologically, the parenchyma of the right ovary presented multiple small surface cysts and CallExner-like bodies in the medulla. Atrophy of the left ovary parenchyma was confirmed, the compression exerted by a mass composed of a proliferation of well-differentiated nervous tissue (Figure2 A to D), surrounded by a dense connective tissue. Neoplastic cells showed strong cytoplasmic immunoreactivity against both S-100 and NSE, occasional positivity to vimentin, but were negative to tested CKs and inhibin (Figure2 E to $\mathrm{H}$ ). The surface epithelium showed strong immunoreactivity to CK AE1-AE3 and CK7, while the stroma was positive to vimentin and interstitial glands positive to inhibin.

The uterus displayed cystic glandular hyperplasia, with a mucopurulent content in the glands and lumen, contaminated with cocci bacteria. In the cranial segment of the left horn, it was observed proliferation of the endometrium showing cellular atypia, aberrant cells with evident nucleoli and mitosis in a papillary disposition, invading the muscular layer. The neoplastic cells were positive to large spectrum keratin and CK7 (Figure 3).

Supported by the histopathological findings, the diagnosis was mature ovarian monophasic teratoma co-existing with an endometrial adenocarcinoma and septic pyometra.

Ethical approval was not deemed necessary for this study; the informed consent of the owners was granted to publicly describe the current case.

This article is protected by copyright. All rights reserved. 


\section{Discussion}

Ovarian and endometrial tumors are considered rare in dogs, albeit some bias may result from the customary practice of spaying in early ages (Saba and Lawrence 2012). Ovarian teratomas are the less common type of ovarian neoplasms in female dogs. They are characterized by proliferation of any tissue of embryonic origin (e.g. skin, sebaceous glands, hair follicles, adipocytes or nervous tissue, among others). In the case described herein, a proliferation of only one type of germinative cell (nervous tissue) was observed, and consequently a diagnosis of monophasic mature teratoma was established. To the authors' knowledge, only one other case of was previously reported in dogs, in an ovarian remnant of a 5-years-old mixed bred bitch (Rota et al. 2013).

The morphological appearance of the neoplastic cells in the H-E staining clearly evidenced the neural origin of tumor cells, as further confirmed by the positive immunoreactivity against NSE, S-100 and vimentin. On the atrophic ovarian parenchyma, positivity to vimentin, CK A1/A3, CK7 and inhibin confirmed the presence of typical ovarian components. The negative labelling for keratin and inhibin in the neoplastic cells excluded the presence of tissues from other origins in the teratoma and other ovarian tumors.

Adenocarcinomas are considered rare neoplasm in the canine uterus (Maya-Pulgarin et al. 2017), contrasting to other domestic species (Kennedy et al. 1998), including the queen (Saraiva et al. 2015). Dogs tend to develop degenerative and inflammatory conditions of the endometrium (e.g., cystic hyperplasia and pyometra) with age and in response to irritative stimuli (Payan-Carreira and Pires 2016).

Clinical signs associated with endometrial adenocarcinomas depend upon the tumor size and the presence of metastatic disease or other comorbidities. They are often clinically masked by signs common to most genital tract diseases (Payan-Carreira and Pires 2016), such as vaginal discharge. Other clinical signs include anorexia and abdominal discomfort or enlargement. Adenocarcinomas might be underdiagnosed in dogs due to an inadequate post-surgical or post-mortem evaluation of the genital tract. As the clinical signs are often misinterpreted as pyometra or abortion, the histopathological evaluation of genital apparatus is seldom required.

In the present case, the same patient presented two rare tumors: a monophasic teratoma and an endometrial adenocarcinoma. This diagnosis was only possible after a careful and detailed histopathological evaluation, emphasizing the importance of this exam. Immunohistochemistry confirmed the presence of only neuronal tissue on the teratoma and determined the endometrial

This article is protected by copyright. All rights reserved. 
origin of the uterine lesion, proving the usefulness to differentiate and describe different tumor cell populations.

\section{Acknowledgements}

The authors acknowledge the technical support of Ligia Lourenço, Gustavo Paixão for language editing and to CECAV for the use of the digital image acquisition software Nikon NIS-Elements $D$ (found by PEst-OE/AGR/UI0772/2014) and also the owners of the female dog for granting permission to publish this case.

\section{Conflict of interests}

The authors have no conflict of interests to declare.

\section{References}

Coggeshall, J., Franks, J., Wilson, D. \& Wiley, J. (2012). Primary ovarian teratoma and GCT with intraabdominal metastasis in a dog. J. Am. Anim. Hosp. Assoc. 48 (6): 424-428 doi:10.5326/JAAHA-MS5809

Greenlee, P. \& Patnaik, A. (1985). Canine Ovarian Tumors of Germ Cell Origin. Veterinary Pathology, 22: 117-122. doi: doi.org/10.1177/030098588502200204

Kennedy, P., Cullen, J., Edwards, J., Goldschmidt, M, Larsen, S., Munson, L. \& Nielsen, S. (1998). Histological Classification of Tumors of Genital System of Domestic Animals, 2nd ed. Vol. IV. World Health Organization and Armed Forces Institute of Pathology, Washington, DC, pp. 32.

Maya-Pulgarin, D., Gonzalez-Dominguez, M., Aranzazu-Taborda, D., Mendoza, N. \& MaldonadoEstrada, J. (2017). Histopathologic findings in uteri and ovaries collected from clinically healthy dogs at elective ovariohysterectomy: a cross-sectional study. Journal of Veterinary Science 18 (3): 407 414 doi: 10.4142/jvs.2017.18.3.407

Nagashima, Y., Hoshi, K., Tanaka, R., Shibazaki, A., Fujiwara, K., Konno, K., Machida, N. \& Yamane, Y. (2000). Ovarian and Retroperitoneal Teratomas in a Dog. Journal of Veterinary Medicine Science 62 (7): 793-795 doi: doi.org/10.1292/jvms.62.793

Payan-Carreira, R. \& Pires, M.A. (2016). The Value of a Routine Histopathological Examination of Uterine Specimens in Dogs and Cats. In Histopathology, ed. SM Group Open Access eBooks, Dover, DE 19904, USA.: 1-14.

Pires, M.A., Seixas, F., Palmeira, C. \& Payan-Carreira, R. (2010). Histopathologic and Immunohistochemical exam in one case of canine endometrial adenocarcinoma. Reproduction in Domestic Animals 45, 545-549 doi: doi.org/10.1111/j.1439-0531.2008.01243.x

Rota, A., Tursi, M., Zabarino, S. \& Appino, S., (2013). Monophasic Teratoma of the Ovarian Remnant in a Bitch. Reproduction in Domestic Animals 48 (2) e26-e28. doi: doi.org/10.1111/rda.12090

This article is protected by copyright. All rights reserved. 
Saba, C. \& Lawrence, J. (2012). Tumors of the female reproductive system. In: Withrow SJ, Vail DM, eds. Withrow and MacEwen's small animal clinical oncology. 5th ed. St. Louis (MO): Saunders Elsevier: 610-8.

Saraiva, L., Payan- Carreira, R., Gartner, F., Santana, I., Rêma, A., Lourenço, L. \& Pires M.A. (2015). Immunohistochemical expression of cyclooxygenase-2 (COX-2) in feline endometrial adenocarcinoma and in normal and hyperplastic endometria. Reproduction in Domestic Animals. 50 (2): 333-340. doi: doi.org/10.1111/rda.12497

This article is protected by copyright. All rights reserved. 
Table 1: Antibodies used to characterize the ovarian and endometrial lesions

\begin{tabular}{|c|c|c|c|c|c|c|}
\hline Antibody & $\begin{array}{l}\text { Target structure/tissue } \\
\text { (intensity) }\end{array}$ & Clone & Supplier & Dilution & Antigen retrieval & Incubation \\
\hline $\begin{array}{l}\text { NSE - Neuron } \\
\text { Specific Enolase }\end{array}$ & $\begin{array}{l}\text { Nerve bundles in the ovary } \\
\text { (moderate) } \\
\text { Nervous cells (in teratoma) } \\
\text { Neuroendocrine cells (weak } \\
\text { to moderate) }\end{array}$ & $\begin{array}{l}\text { E27 Ab1 (mouse } \\
\text { monoclonal } \\
\text { antibody) }\end{array}$ & $\begin{array}{l}\text { Thermo Fisher } \\
\text { Scientific, United } \\
\text { Kingdom }\end{array}$ & $1: 400$ & \multirow{4}{*}{ Citrate, $\mathrm{pH} 6 ; 1$ cycle 5' MW } & room temperature, 2 hours \\
\hline S-100 & $\begin{array}{l}\text { Rete ovarii \& stromal cells } \\
\text { (strong) } \\
\text { Nervous cells (in teratoma) }\end{array}$ & $\begin{array}{l}\text { NCL-S100p (rabbit } \\
\text { polyclonal } \\
\text { antibody) }\end{array}$ & $\begin{array}{l}\text { Novocastra, } \\
\text { United Kingdom }\end{array}$ & $1: 100$ & & $4^{\circ} \mathrm{C}$, Overnight \\
\hline VIMENTIN & $\begin{array}{l}\text { Ovarian stroma (strong) } \\
\text { Surface epithelium and sub- } \\
\text { surface epithelial structures } \\
\& \text { rete ovarii (irregular) } \\
\text { Granulosa cells (moderate) }\end{array}$ & $\begin{array}{l}\text { NCL-L-Vim-V9 } \\
\text { (mouse monoclonal } \\
\text { antibody) }\end{array}$ & $\begin{array}{l}\text { Novocastra, } \\
\text { United Kingdom }\end{array}$ & $1: 50$ & & $4^{\circ} \mathrm{C}$, Overnight \\
\hline CK AE1/AE3 & $\begin{array}{l}\text { Surface epithelium, sub- } \\
\text { surface epithelial structures } \\
\text { (strong) } \\
\text { rete ovarii (moderate) } \\
\text { Endometrial epithelium } \\
\text { Uterine epithelia }\end{array}$ & $\begin{array}{l}\text { AE1/AE3 (mouse } \\
\text { monoclonal } \\
\text { antibody) }\end{array}$ & Dako ${ }^{\oplus}$ Corp., USA & $1: 100$ & & $4^{\circ} \mathrm{C}$, Overnight \\
\hline INHIBIN alpha & $\begin{array}{l}\text { Granulosa cells (moderate } \\
\text { to strong) }\end{array}$ & $\begin{array}{l}\text { MCA951S (mouse } \\
\text { monoclonal } \\
\text { antibody) }\end{array}$ & $\begin{array}{l}\text { Bio-Rad Serotec, } \\
\text { USA }\end{array}$ & $1: 25$ & $\begin{array}{l}\text { Citrate, } \mathrm{pH} 6 ; 3 \text { cycles } 5 \text { ' } \\
\text { MW }\end{array}$ & $4^{\circ} \mathrm{C}$, Overnight \\
\hline 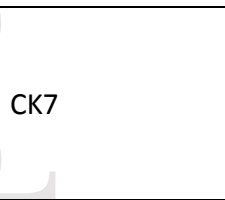 & $\begin{array}{l}\text { Surface ovarian epithelium } \\
\text { (moderate) } \\
\text { Sub-surface epithelial } \\
\text { structures (weak) } \\
\text { Endometrial epithelium }\end{array}$ & $\begin{array}{l}\text { R17-S (rabbit } \\
\text { polyclonal } \\
\text { antibody) }\end{array}$ & $\begin{array}{l}\text { DB Biotech, } \\
\text { Slovakia }\end{array}$ & $1: 50$ & $\begin{array}{l}\text { Citrate, pH 6; 3' pressure } \\
\text { cooker }\end{array}$ & $4^{\circ} \mathrm{C}$, Overnight \\
\hline
\end{tabular}

This article is protected by copyright. All rights reserved. 

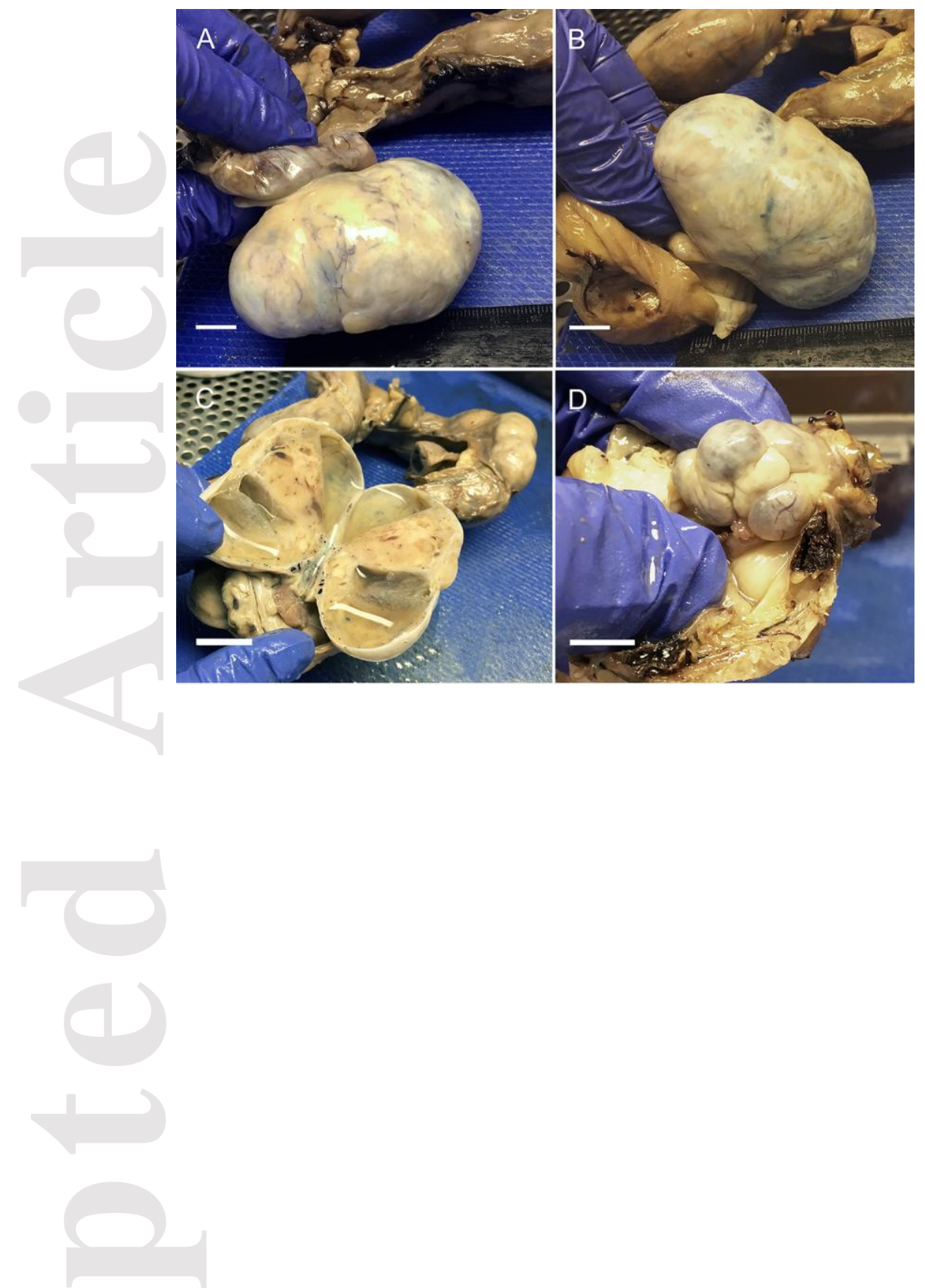

This article is protected by copyright. All rights reserved. 


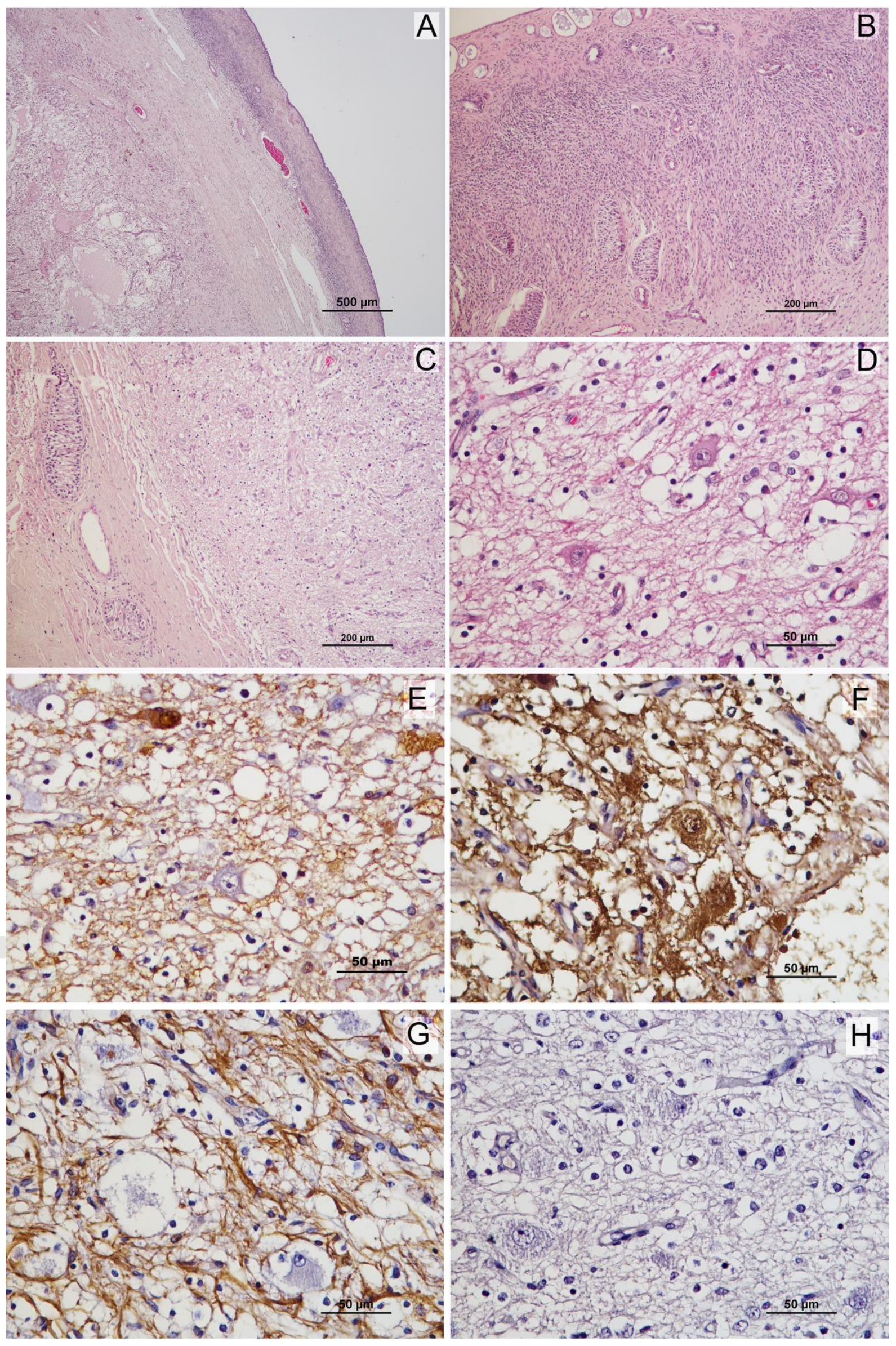

This article is protected by copyright. All rights reserved. 

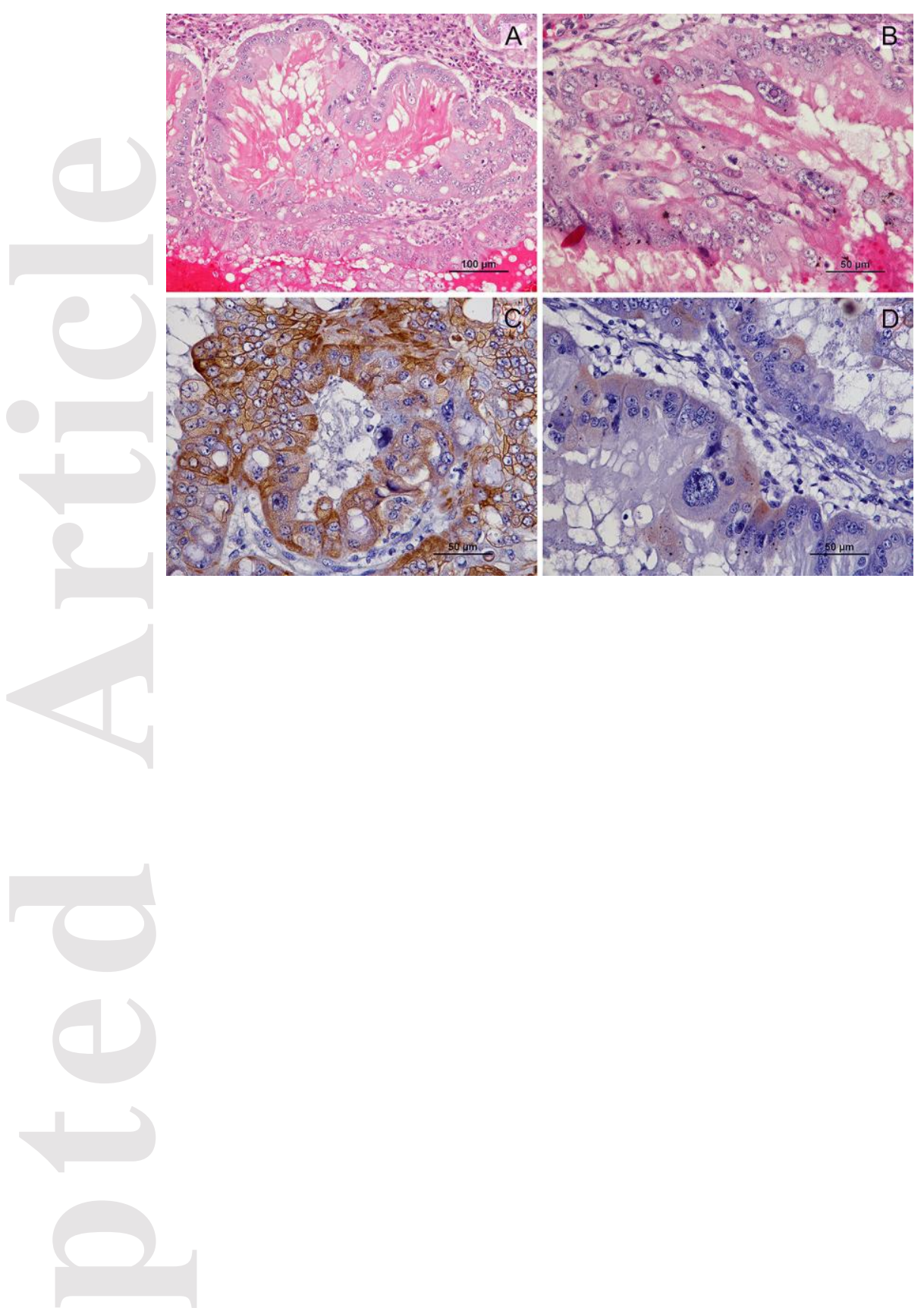

This article is protected by copyright. All rights reserved. 
Supplementary Table 1 - Hematology tests results at admission

\begin{tabular}{|c|c|c|c|}
\hline Parameter & Units & Results & Reference range \\
\hline WBC & $10^{\wedge} 3 / \mathrm{uL}$ & 16.14 & $6.0-17.0$ \\
\hline \multirow{2}{*}{ Neutrophils } & $10^{\wedge} 3 / \mathrm{uL}$ & 13.66 & $3.62-12.30$ \\
\hline & $\%$ & 84.6 & $52.0-81.0$ \\
\hline \multirow{2}{*}{ Lymphocytes } & $10^{\wedge} 3 / \mathrm{uL}$ & 1.12 & $0.83-4.91$ \\
\hline & $\%$ & 7.0 & $12.0-33.0$ \\
\hline \multirow{2}{*}{ Monocytes } & $10^{\wedge} 3 / \mathrm{uL}$ & 1.26 & $0.04-1.62$ \\
\hline & $\%$ & 7.8 & $2.0-13.0$ \\
\hline \multirow{2}{*}{ Eosinophils } & $10^{\wedge} 3 / \mathrm{uL}$ & 0.07 & $0.04-1.62$ \\
\hline & $\%$ & 0.5 & $0.5-10.0$ \\
\hline \multirow{2}{*}{ Basophiles } & $10^{\wedge} 3 / \mathrm{uL}$ & 0.03 & $0.00-0.12$ \\
\hline & $\%$ & 0.1 & $0.0-1.3$ \\
\hline $\mathrm{RBC}$ & $10^{\wedge} 6 / \mathrm{uL}$ & 6.22 & $5.10-8.50$ \\
\hline HBG & $\mathrm{g} / \mathrm{dL}$ & 14.4 & $11.0-19.0$ \\
\hline HCT & $\%$ & 42.7 & $33.0-56.0$ \\
\hline $\mathrm{MCV}$ & $\mathrm{fL}$ & 68.7 & $60.0-76.0$ \\
\hline $\mathrm{MCH}$ & pg & 32.2 & $20.0-27.0$ \\
\hline $\mathrm{MCHC}$ & $\mathrm{g} / \mathrm{dL}$ & 33.7 & $30.0-38.0$ \\
\hline PLT & $10^{\wedge} 3 / \mathrm{uL}$ & 167 & $117-490$ \\
\hline MPV & $\mathrm{fL}$ & 10.4 & $8.0-14.1$ \\
\hline PDW & & 17.5 & $12.0-17.5$ \\
\hline PCT & $\%$ & 0.174 & $0.090-0.580$ \\
\hline
\end{tabular}


Supplementary Table 2 - Serum biochemistry tests results at admission [Fujifilm DryChem NX500i]

\begin{tabular}{llcc}
\hline Parameter & Units & Results & Reference range \\
\hline BUN & $\mathrm{mg} / \mathrm{dL}$ & 15.2 & $9.2-29.2$ \\
\hline Creatinin & $\mathrm{mg} / \mathrm{dL}$ & 0.6 & $0.4-1.4$ \\
\hline Glucose & $\mathrm{mg} / \mathrm{dL}$ & 112 & $76-119$ \\
Serum total protein & $\mathrm{g} / \mathrm{dL}$ & 6.4 & $5.4-7.5$ \\
\hline
\end{tabular}

